\title{
Hyaluronidase-inhibitory activities of glycosaminoglycans from Liparis tessellatus eggs
}

Ticar, Bernadeth F. ; Rohmah, Zuliyati ; Mussatto, Solange Ines; Lim, Jae-Min ; Park, Seongha ; Choi, Byeong-Dae

\section{Published in:}

Carbohydrate Polymers

Link to article, DOI:

10.1016/j.carbpol.2016.12.065

Publication date:

2017

Document Version

Peer reviewed version

Link back to DTU Orbit

Citation (APA):

Ticar, B. F., Rohmah, Z., Mussatto, S. I., Lim, J-M., Park, S., \& Choi, B-D. (2017). Hyaluronidase-inhibitory activities of glycosaminoglycans from Liparis tessellatus eggs. Carbohydrate Polymers, 161, 15-20.

https://doi.org/10.1016/j.carbpol.2016.12.065

\section{General rights}

Copyright and moral rights for the publications made accessible in the public portal are retained by the authors and/or other copyright owners and it is a condition of accessing publications that users recognise and abide by the legal requirements associated with these rights.

- Users may download and print one copy of any publication from the public portal for the purpose of private study or research.

- You may not further distribute the material or use it for any profit-making activity or commercial gain

- You may freely distribute the URL identifying the publication in the public portal 


\title{
Hyaluronidase-inhibitory activities of glycosaminoglycans from Liparis tessellatus eggs
}

\author{
Bernadeth F. Ticara,b,*, Zuliyati Rohmaha,c, Solange I. Mussatto ${ }^{\mathrm{d}}$, Jae-Min Lim ${ }^{\mathrm{e}}$, \\ Seongha Park ${ }^{\mathrm{e}}$, and Byeong-Dae Choi ${ }^{\mathrm{a}}$
}

${ }^{a}$ Department of Seafood and Aquaculture Science, College of Marine Science, Gyeongsang National University, 38 Cheondaegukchi-gil, Tongyeong, Gyeongnam 650-160, South Korea

${ }^{b}$ College of Arts and Sciences, Iloilo Science and Technology University, Burgos St., La Paz, Iloilo City 5000, Iloilo, Philippines

${ }^{c}$ Faculty of Biology, Universitas Gadjah Mada, Yogyakarta 55281, Indonesia

${ }^{d}$ Novo Nordisk Foundation Center for Biosustainability, Technical University of Denmark, Kemitorvet, Building 220, 2800, Kongens Lyngby, Denmark

${ }^{e}$ Department of Chemistry, Changwon National University, Changwon 53210, South Korea

Highlights

- $\quad$ ESI-MS/MS showed the presence of uronic acids from L. tessellatus eggs

- Hyaluronidase inhibitory effect of sulfated hyaluronic acid from L. tessellatus eggs

- Uronic acids from L. tessellatus eggs have hyaluronidase inhibitory effects 


\begin{abstract}
Polysaccharide fractions isolated from L. tessellatus eggs were purified and eluted using the DEAE-sepharose fast flow column. These were collected, tested and pooled based on their sugars content: F1, F2, and F3 which contain 26.8, 23.3, and 20.2\% sulfated glycans; 34.5, 38.2, and 45.0\% uronic acids; and 23.5, 19.0, and 7.5\% acetylhexosamines and hexosamines, respectively. Hyaluronidase inhibitory effects of the fractions are in the order F3 $>$ F2 $>$ F1 $>$ Ascorbic acid, with F3 having the highest inhibition among the fractions and that of the standard, ascorbic acid. The ESI-MS/MS confirmed the presence of uronic acids on F3, which could be a ${ }^{0,2} \mathrm{~A}_{2}$ fragment plus loss of methyl group which is very common among nonmethylated, sulfated disaccharides.
\end{abstract}

Keywords: L. tessellatus eggs, hyaluronidase inhibitory effect, hyaluronic acid

\title{
1. Introduction
}

Hyaluronic acid and chondroitin sulfate are constituents of the amorphous substances of connective tissues (Mase, Yamauchi, Kato, Esaki, \& Isshiki, 2013). Such compounds are natural glycosaminoglycans consisting of D-glucuronic acid and N-acetyl-D-glucosamine repeating disaccharide units, and a sulfated glycosaminoglycan composed of Nacetylgalactosamine and glucuronic acid, respectively. Hyaluronidase inhibitors act upon hyaluronidase (EC 3.2.1.35) enzyme, which degrades hyaluronic acid and chondroitin sulfate. As a consequence, hyaluronidase inhibitors are effective in suppressing allergies and inflammation (Furusawa, Narita, Iwai, Fukunaga, \& Nakagiri, 2011) where the interaction of hyaluronidase with hyaluronic acid disrupts basement membrane integrity and produces an angiogenic response, in which the enzyme mediates inflammation via histamine release from 
mast cells (Mase et al., 2013). These compounds are potent regulators that maintain hyaluronidase homeostasis and might serve as anti-inflammatory (Girish, Kemparaju, Nagaraju, \& Vishwanath, 2009) and anti-allergen agents (Mase et al., 2013), wherein they counteract the implication of hyaluronidase in tumor invasiveness and homeostasis (Madan et al., 1999).

A number of studies have reported that polysaccharides have hyaluronidase-inhibitory effects. Mase et al. (2013) reported the hyaluronidase-inhibitory activity of a polysaccharide obtained from the unicellular marine alga Porphyridium purpureum. A high inhibitory effect of an acidic polysaccharide from coffee silverskin on hyaluronidase was also reported by Furusawa et al. (2011). Hyaluronidase activity from Naja naja venom was also inhibited by plant-derived bioactive components and polysaccharides, making possible its use as first aid agents in snakebite therapy (Girish \& Kempar bb aju, 2005).

The fish species, L. tessellatus is a very good candidate for polysaccharides extraction, since it has low lipid content $(0-0.10 \%)$ (Lee et al., 2012) and high carbohydrate content of almost $19.50 \pm 1.1 \%$ (Ticar et al., 2015). Its eggs contain mucopolysaccharides which are known for its anticoagulant and anti-thrombotic properties (Arivuselvan et al., 2011; Ticar et al., 2015). Given these data for this fish sample, we subjected the polysaccharide fractions of its eggs for hyaluronidase inhibitory effects. Finally, the fraction with the highest hyaluronidase inhibition was characterized by mass spectrometry to confirm its hyaluronic acid nature.

These polysaccharides from L. tessellatus eggs could be used as materials in functional foods with anti-allergenic and anti-inflammatory activities. In addition, among sources of polysaccharides evaluated, specifically on marine organisms, this study is novel, since it made use of fish eggs as another source of bioactive polysaccharides. 


\section{Materials and methods}

\subsection{Materials and chemicals}

Liparis tessellatus eggs were purchased from a fresh market in Tongyeong, Korea. DEAE-sepharose gel, D-glucose, hyaluronic acid, chondroitin sulfate, and hyaluronidase were obtained from Sigma-Aldrich Chemicals (MO, USA). All other chemicals were of analytical grade.

\subsection{Isolation and purification of polysaccharides from L. tessellatus eggs (PLE)}

Polysaccharides from Liparis tessellatus eggs (PLE) were isolated according to the methodology described by Ticar et al. (2015). For purification, a concentration of $10 \mathrm{mg} / \mathrm{ml}$ of polysaccharide sample was dissolved in deionized water, filtered in a $0.2-\mu \mathrm{m}$ membrane and applied to a DEAE-sepharose ${ }^{\mathrm{TM}}$ fast flow column $(2.5 \times 30 \mathrm{~cm})$. The column was equilibrated with $0.5 \mathrm{M}$ sodium phosphate buffer $(\mathrm{pH} 6.5$ ) and a linear gradient of $0-2.0 \mathrm{~mol} / \mathrm{L} \mathrm{NaCl}$ prepared in the same buffer at a flow rate of $0.5 \mathrm{ml} / \mathrm{min}$. Fractions were collected, checked for total carbohydrate content and pooled together based on their sugars content. Each pooled fraction was dialyzed against deionized water by continuous diafiltration until total dissolved solids was equal to zero. This step was performed using a Pellicon UF membrane (Millipore Corp., Mass., USA) with a molecular weight cut-off of $10 \mathrm{kDa}$. After dialysis, the fractions were lyophilized and labeled as F1, F2, and F3.

\subsection{Analytical methods}

\subsubsection{Polysaccharides composition}

Total carbohydrate content was estimated by the phenol-sulphuric acid method using Dglucose as standard (Dubois et al., 1956). Uronic acids, sulfates, and hexosamines contents in 
each dialyzed fraction were measured accordingly by using carbazole (Cesaretti, Luppi, \& Volpi, 2003) metachromasia (Keler \& Nowotny, 1986) and MBTH (Anthon \& Barrett, 2002) assays, respectively.

\subsubsection{Hyaluronidase inhibition}

The hyaluronidase inhibition assay was performed according to the method described by Yahaya \& Don (2012) with some modifications. Three concentrations $(2.0,4.0$, and 8.0 $\mathrm{mg} / \mathrm{ml}$ ) of F1, F2, and F3 were prepared. The assay medium consisted of $100 \mu 1$ of hyaluronidase, $100 \mu \mathrm{l}$ of sodium phosphate buffer $\left(100 \mathrm{mM}, \mathrm{pH} 7,37^{\circ} \mathrm{C}\right)$ with $50 \mathrm{mM} \mathrm{NaCl}$ and $0.01 \% \mathrm{BSA}$, which were mixed with $50 \mu \mathrm{l}$ of sample solution and incubated at $37^{\circ} \mathrm{C}$ for $10 \mathrm{~min}$. The reaction was then initiated by the addition of $100 \mu \mathrm{l}$ of the substrate in the form of hyaluronic acid solution $(0.03 \%$ in $300 \mathrm{mM}$ sodium phosphate, $\mathrm{pH} 5.35)$ and incubated at $37^{\circ} \mathrm{C}$ for $45 \mathrm{~min}$. The undigested hyaluronic acid was precipitated with $1.0 \mathrm{ml}$ acid albumin solution $(0.1 \%$ BSA in $24 \mathrm{mM}$ sodium acetate and $79 \mathrm{mM} \mathrm{CH} 3 \mathrm{COOH}, \mathrm{pH} 3.75)$. The mixture was left to stand for $10 \mathrm{~min}$ at room temperature and the absorbance of the reaction mixtures were measured at $600 \mathrm{~nm}$ using Spectramax M2 (Molecular Devices, Sunnyvale, CA, USA). All solutions were freshly prepared before the enzyme assay was performed. The absorbance in the absence of enzyme was used as control for maximum inhibition. Ascorbic acid was used as positive control. The percentage of inhibition was calculated as:

$$
\% \text { Inhibition }=\left(\mathrm{Ab}_{\mathrm{s}} / \mathrm{Ab} \mathrm{b}_{\mathrm{c}}\right) \times 100
$$

where; $\mathrm{Abc}=$ absorbance of control; $\mathrm{Abs}=$ absorbance of sample. All the reactions were performed in triplicate.

\subsubsection{Enzyme hydrolysis of polysaccharide fractions and mass spectrometric (MS) analysis}


The polysaccharide fractions (F1, F2, and F3) together with the standard hyaluronic acid were dissolved in $100.0 \mathrm{mM}$ sodium phosphate/150.0 mM sodium chloride buffer, $\mathrm{pH}$ 5.3. The samples were incubated at $37^{\circ} \mathrm{C}$ with hyaluronidase from bovine testes and chondroitinase $\mathrm{ABC}$. The digestion sample was heated at $100^{\circ} \mathrm{C}$ for $5 \mathrm{~min}$, then, freeze-dried.

Freeze-dried samples were then permethylated using $\mathrm{NaOH}$ in anhydrous DMSO (dimethyl sulfoxide), followed by treatment with iodomethane. Briefly, in a glass test tube, $100 \mu \mathrm{l}$ of $50 \% \mathrm{NaOH}$ and $200 \mu \mathrm{l}$ of anhydrous methanol were mixed together and vortexed. The $\mathrm{NaOH}$ suspension was cleaned with anhydrous DMSO several times. Samples were dissolved in $200 \mu \mathrm{l}$ of dry DMSO by vortexing, then $300 \mu \mathrm{l}$ of $\mathrm{NaOH}$ suspension in anhydrous DMSO was added, followed by $150 \mu$ l iodomethane. After mixing for 5 min by vortex, the mixture was sonicated for $10 \mathrm{~min}$. The reaction was quenched by adding $2 \mathrm{ml}$ of water. The excess iodomethane was removed by bubbling with nitrogen gas. Methylene chloride was added to extract the methylated hyaluronic acid by phase separation. Methylene chloride phase was then evaporated. The methylated polysaccharides were dissolved in $50 \mu 1$ of $80 \%$ methanol in $1.0 \mathrm{mM} \mathrm{NaOH}$ for MS analysis on a Thermo LCQ ion trap instrument using direct infusion ESI-MS. Eighty percent methanol in $1.0 \mathrm{mM} \mathrm{NaOH}$ was used as spray solvent. The sample was introduced by direct infusion at a flow rate of $1 \mu \mathrm{l} / \mathrm{min}$ using a Harvard syringe pump. The capillary temperature was $200^{\circ} \mathrm{C}$ and the absolute value of the spray voltage was $3.5 \mathrm{kV}$ in positive ion mode. $\mathrm{MS}^{\mathrm{n}}$ experiments were carried out in positive ion mode and profile mode with normalized collision energy of $30 \%$.

\section{Results and discussion}

\subsection{Fractionation and chemical composition of polysaccharides from L. tesellatus eggs}

Polysaccharides isolated from L. tesellatus eggs (PLE) were composed of $43.2 \%$ total 
sugars, $12.0 \%$ sulfates, $23.9 \%$ uronic acids, and $1.7 \%$ hexosamine contents. After elution/ fractionation of PLE using a DEAE-sepharose fast flow column chromatography, fractions were collected and pooled according to their sugars compositions obtaining: F1 (fractions 3948), F2 (fractions 53-69), and F3 (fractions 72-79) (Fig. 1). These fractions were collected, dialyzed, lyophilized, and then tested for total sugar, sulfates, uronic acids, and hexosamines contents (Table 1).The constituents of each pooled fraction were: total sugar (78.0-88.5\%), sulfates (20.2-26.8\%), uronic acids (34.5-45.0\%), and hexosamines (7.5-23.5\%) for F1, F2, and F3, respectively. These results indicate variations in the ionic strengths of each fraction, which is in agreement with the study conducted by Tabarsa, Han, Kim, \& You (2012) on the water-soluble polysaccharides from Ulva pertusa, wherein, fractionation of a crude polysaccharide using ion-exchange chromatography also gave fractions of various ionic strengths with different compositions.

\subsection{Hyaluronidase inhibitory effects of polysaccharide fractions}

Hyaluronidase is an endo-hexosaminidase that initiates the degradation of high molecular weight hyaluronic acid (Moon et al., 2009). The inhibitory effects of fractions F1, F2, and F3 were evaluated toward hyaluronidase using ascorbic acid as standard (Fig. 2). In this method, the hyaluronidase inhibitory effect is inversely proportional to the transmittance of light as measured at a wavelength of $595 \mathrm{~nm}$. The precipitate formed after treatment of hyaluronidase was the amount of undigested hyaluronic acid which blocked the transmission of light into the solution. Thus, the lower the transmittance means the greater the amount of hyaluronic acid left undigested by hyaluronidase and consequently, higher inhibitory effect. The inhibitory capacity of the three fractions, including the standard is in the order: Ascorbic acid $<$ F1 $<$ F2 $<$ F3. Specifically, all the three fractions have higher inhibitions compared with ascorbic acid, a potent hyaluronidase inhibitor (Botzki et al., 2004), with F3 having the highest activity. From Table 1, it can be observed that F3 has the highest content of uronic 
acids $(45.0 \%)$, when compared to the other two fractions. Thus, the high activity of F3 could be attributed to its uronic acids content. In addition, the presence of sulfated glycans in this fraction (Table 1) might probably have a synergistic action with uronic acids increasing its hyaluronidase inhibition. In a study by Schulz et al. (2009), they noticed an anti-inflammatory potential of a hyaluronic acid containing chondroitin sulfate preparation in the treatment of interstitial cystitis and BPS (bladder pain syndrome), yet an imperfectly understood disease, possibly originating from damage to the glycosaminoglycan layer of the bladder epithelium. This observation can affirm the hyaluronidase inhibitory effect of F3 fraction, since, as a hyaluronidase inhibitor, it can deter HA fragmentation which can promote inflammation (Girish et al., 2009). In line with this observation, sulfated hyaluronic acid (sHA) (Benitez et al., 2011; Furusawa et al., 2011) was found out to inhibit the activity of hyaluronidases by a mixed inhibition mechanism, where the tumor-derived hyaluronidase was found out to be inhibited by sHA, a nontoxic hyaluronidase inhibitor. At the same time, sHA also delineated the molecular mechanism through which hyaluronic acid-hyaluronidase (HA-HAase) system might mediate tumor growth and progression, since HA-HAase is known to promote tumor growth and metastasis (Simpson \& Lokeshwar, 2008). Hence, inhibition of HA degradation appears critical and imperative in HAase mediated pathological conditions (Girish et al., 2009).

\subsection{Analysis of hyaluronic acids on polysaccharide fractions by mass spectrometry}

The polysaccharide fraction, F3, having the highest hyaluronidase-inhibitory activity among the three fractions was characterized by mass spectrometry. Figure 4 shows the full ESI-MS spectra of permethylated hyaluronic acids from hyaluronic acid standard and F3 of $L$. tesellatus eggs. Fig. 4(a) shows the repeat unit of hyaluronic acid and Fig. 4(b) lists the hyaluronic acids according to the number of repeat unit. The mass spectrum of permethylated 
hyaluronic acid from standard is depicted in Fig. 4(c) which is presented as the repeat unit from 1 to 4. Figure 4(d) shows the Hyaluronic acids detected in F3 of L. tesellatus eggs.

The structures of these hyaluronic acids were confirmed by ESI-MS/MS, which are shown in Fig. 5. The m/z 356.1 in Fig. 5(a) could either be a ${ }^{2,5} \mathrm{~A}_{2}$ cross ring fragment or a ${ }^{0,2} \mathrm{~A}_{2}$ fragment plus loss of methyl group. In non-methylated sulfated disaccharides the ${ }^{0,2} \mathrm{~A}_{2}$ fragment is very common, so the second possibility may be more likely.

The unsaturation into the uronic acid moiety at 4,5 position $(\mathrm{m} / \mathrm{z}=964.8$, Fig. 4) which was detected on F3, was possibly due to the mechanism of enzyme action which involved splitting of a glycosidic bond by elimination reaction, thereby introducing unsaturation in the liberated molecules (Meyer, Davidson, Linker, \& Hoffman, 1956). With this data on the characterization of the F3 fraction, its high hyaluronidase-inhibitory activity can be attributed to its high uronic acids content (Table 1) as confirmed in its mass spectrometric analysis. To relate the significance of the 4,5 position of unsaturation of the HA from the mass spectrometric analysis to the isolated HA from the F3 fraction of L. tessellatus eggs, an electrophilic addition reaction will likely occur at the unsaturation site (Carey \& Sundberg, 2007) and will yield O-sulfated HA, since sulfate molecules are present (Table 1) in the polysaccharide sample. Relatively, a high hyaluronidase inhibitory effect of chemicallymodified O-sulfated HA as compared with other O-sulfated glycosaminoglycans was also observed by Toida et al (1999).

Given the hyaluronidase inhibiting effect of the polysaccharide fraction (F3) from $L$. tessellatus eggs, this could be used as anti-inflammation and anti-allergen agents.

\section{Conclusions}


This study showed that the polysaccharide fractions isolated from Liparis tessellatus eggs exhibit hyaluronidase-inhibitory effects. Hyaluronic acids were confirmed on F3 fraction (having the highest inhibitory effect against hyaluronidase enzyme). It can be concluded too, that sulfates detected on the polysaccharide fraction F3 may have synergistic effect in its inhibition against hyaluronidase enzyme. These results are of importance in the engineering of new anti-inflammation and anti-allergenic health products.

\section{Acknowledgements}

This research was supported by Basic Science Research Program through the National Research Foundation (NRF) of Korea funded by the Ministry of Education, Science and Technology (Grant number: 2011-0010000).

\section{References}

Anthon, G.E. \& Barrett, D.M. (2002). Determination of Reducing Sugars with 3-Methyl-2benzothiazolinonehydrazone. Analytical Biochemistry, 305, 287-289.

Arivuselvan, N., Radhiga, M., \& Anantharaman, P. (2011). In vitro antioxidant and anticoagulant activities of sulphated polysaccharides from Brown seaweed (Turbinaria ornate) (Turner) J. Agardh. Asian Journal of Pharmaceutical and Biological Research, 1, 232-239.

Benitez, A., Yates, T.J., Lopez, L.E., Cerwinka, W.H., Bakkar, A., \& Lokeshwar, V.B. (2011). Targeting hyaluronidase for cancer therapy: antitumor activity or sulfated hyaluronic acid in prostate cancer cells. Cancer Research, 71(12), 4085-4095.

Botzki, A., Rigden, D., Braun, S., Nukui, M., Salmen, S., Hoechstetter, J., Bernhardt, G.,Dove, S., Jedrzejas, M., \& Buschauer, A. (2004). L-ascorbic acid 6-hexadecanoate, a potent hyaluronidase inhibitor (X-ray structure and molecular modeling of enzyme-inhibitor complexes). The Journal of Biological Chemistry, 279, 45990-45997.

Carey, F.A. \& Sundberg, R.J. (2007). Advanced Organic Chemistry (5 ${ }^{\text {th }}$ ed.). USA: Springer, (Chapter 4).

Cesaretti, M., Luppi, E., Maccari, F., \& Volpi, N. (2003). A 96-well assay for uronic acid carbazole reaction. Carbohydrate Polymers, 54, 59-61. 
Dubois, M., Gilles, K., Hamilton, J., Rebers, P., \& Smith, F. (1956). Analytical Chemistry, 28, 350-356.

Furusawa, M., Narita, Y., Iwai, K., Fukunaga, T., \& Nakagiri, O. (2011). Inhibitory effect of a hot water extract of coffee "silverskin" on hyaluronidase. Bioscience, Biotechnology, and Biochemistry, 75 (6), 1205-1207.

Girish, K.S., Kemparaju, K., Nagaraju, S., \& Vishwanath, B.S. (2009). Hyaluronidase inhibitors: a biological and therapeutic perspective. Current Medicinal Chemistry, 16(18), 2261-2288.

Keler, T. \& Nowotny, A. (1986). Metachromatic assay for the quantitative determination of bacterial endotoxins. Analytical Biochemistry, 156, 189-193.

Lee, D.S., Cho, H.A., Yoon, N.Y., Kim, Y.K., Lim, C.W., \& Shim, K.B. (2012). Biochemical Composition of Muscle from Tanaka's Eelpout Lycodes tanakae, Magistrate Armhook Squid Berryteuthis magister, and Ocean sunfish Mola mola, Caught in the East Sea, Korea. Fisheries and Aquatic Sciences, 15, 99-105.

Madan, A.K., Yu, K., Dhurandhar, n., Cullinane, C., Pang, Y., \& Beech, D.J. (1999). Association of hyaluronidase and breast adenocarcinoma invasiveness. Oncology Reports, 6, 607-609.

Mase, T., Yamauchi, M., Kato, Y., Esaki, H., \& Isshiki, S. (2013). Hyaluronidase-inhibiting acidic polysaccharide isolated from Porphyridium purpureum. 椙山女学 T園大学 研究論, 集, 44, $105-113$.

Meyer, K., Davidson, E., Linker, A., \& Hoffman, P. (1956). The acid mucopolysaccharides of connective tissue. Biochimica et Biophysica Acta, 23, 506-518.

Moon, S., Kim, K., Lee, N., Han, Y., Nah, S., Cho, S., Park, Y., \& Paik, H. (2009). Inhibitory effects of naringenin and its novel derivatives on hyaluronidase. Food Science and Biotechnology, 18, 267-270.

Schulz, A., Vestweber, A.M., \& Dressler, D. (2009). Anti-inflammatory action of a hyaluronic acid-chondroitin sulfate preparation in an in vitro bladder model. Aktuelle Urologie, 40, 109-112.

Simpson, M.A. \& Lokeshwar, V.B. (2008). Hyaluronan and hyaluronidase in genitourinary tumors. Frontiers in Bioscience, 13, 5664-5680. 
Tabarsa, M., Han, J., Kim, C., \& You, S. (2012). Molecular characteristics and immunomodulatory activities of water soluble sulfated polysaccharides from Ulva pertusa. Journal of Medicinal Food, 15, 135-144.

Ticar, B., Rohmah, Z., Ambut, C., Choi, Y., Mussatto, S., \& Choi, B. (2015). Enzyme-assisted extraction of anticoagulant polysaccharide from Liparis tessellatus eggs. International Journal of Biological Macromolecules, 74, 601-607.

Yahaya, Y.A. \& Don, M.M. (2012). Evaluation of Trametes lactinea extracts on the inhibition of hyaluronidase, lipoxygenase and xanthine oxidase activities in vitro. Journal of Physical Science, 23 (2), 1-15.

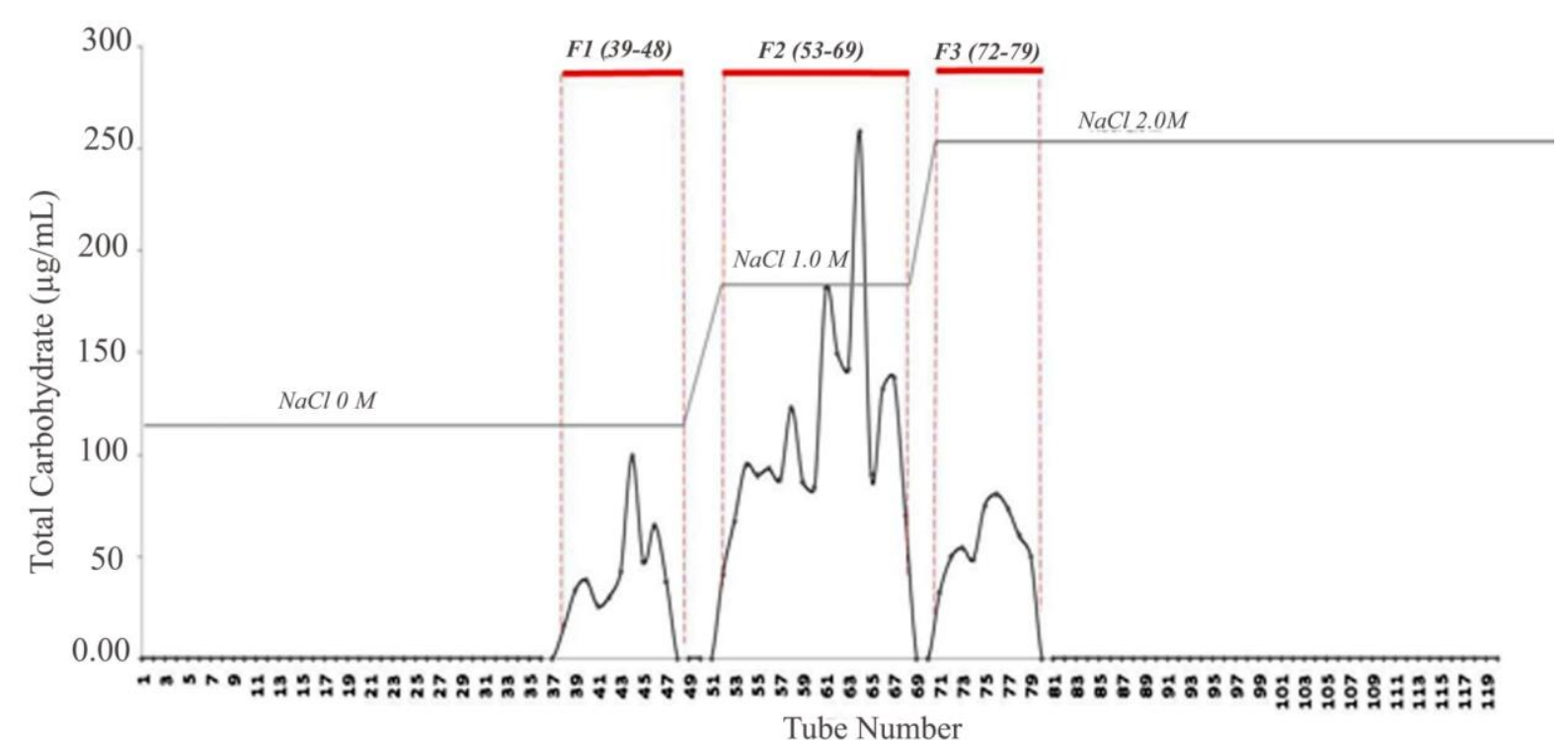

Fig. 1. Elution profiles of polysaccharide fractions isolated from L. tesellatus eggs by DEAEsepharose fast flow column chromatography. Gradient elution was done with $(0-2 \mathrm{M} \mathrm{NaCl})$ in $0.5 \mathrm{M}$ phosphate buffer. The pooling of fractions was based on the monitoring of total sugar content of individual fractions. 


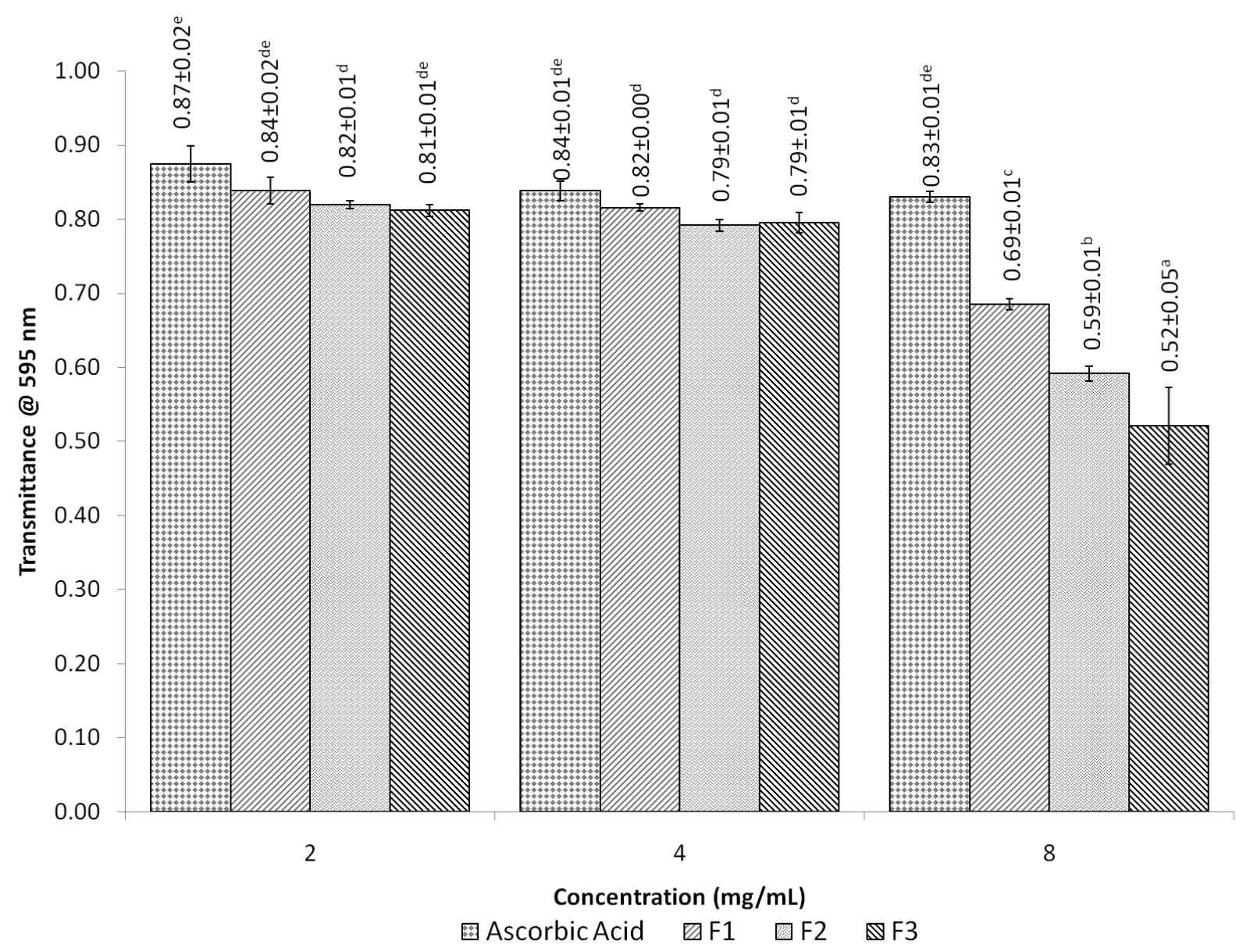

Fig. 2. Hyaluronidase inhibition effects of fraction F1, F2, and F3, obtained by purification of polysaccharides isolated from L. tesellatus eggs, compared with ascorbic acid. Values are means \pm standard deviation of six replicates. Means that do not share a similar letter are significantly different $(\mathrm{p}<0.05)$. 
(a)
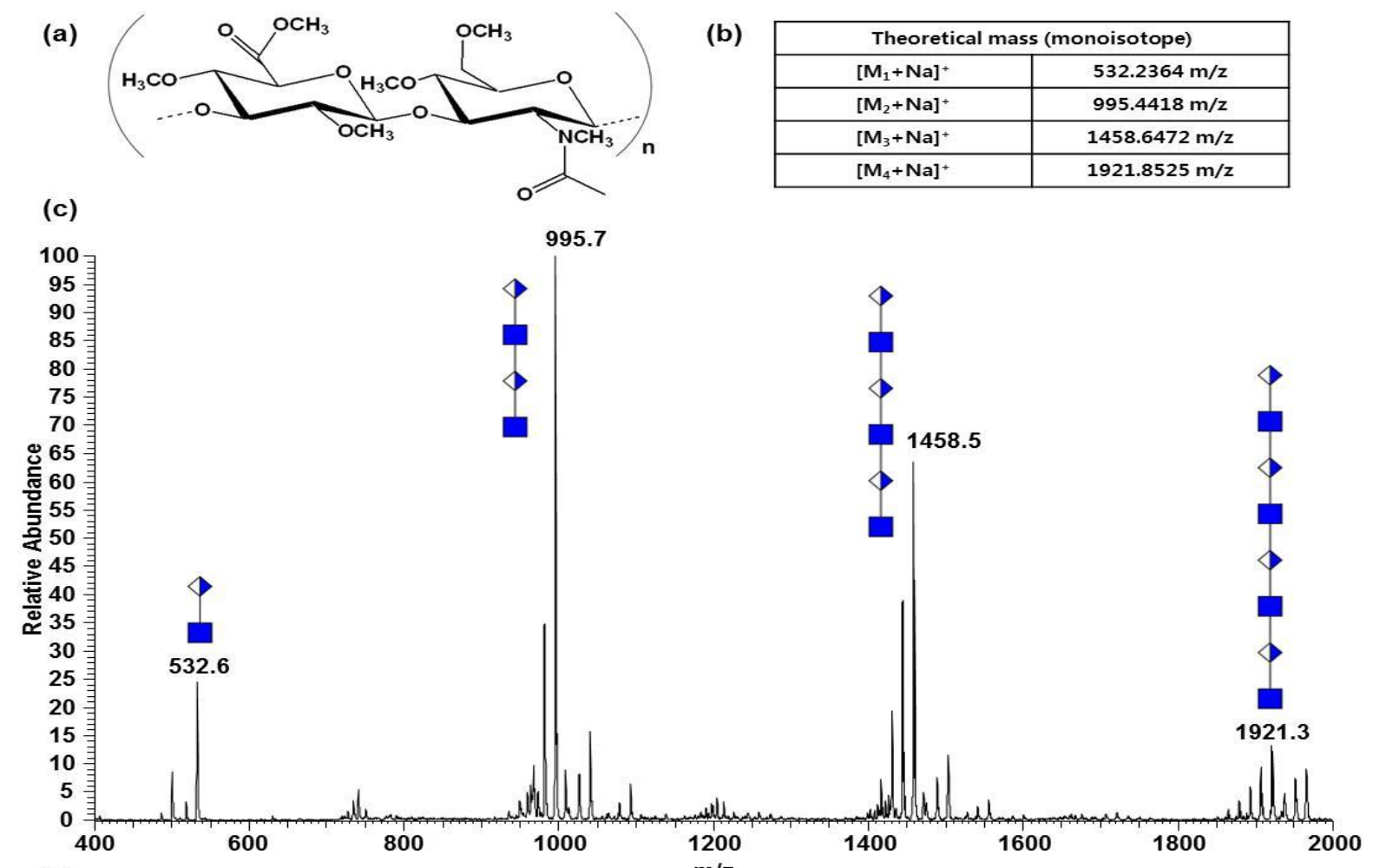

(d)

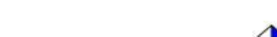
$\mathrm{m} / \mathrm{z}$ (b)

\begin{tabular}{|c|c|}
\hline \multicolumn{2}{|c|}{ Theoretical mass (monoisotope) } \\
\hline$\left[\mathrm{M}_{1}+\mathrm{Na}\right]^{+}$ & $532.2364 \mathrm{~m} / \mathrm{z}$ \\
\hline$\left[\mathrm{M}_{2}+\mathrm{Na}\right]^{+}$ & $995.4418 \mathrm{~m} / \mathrm{z}$ \\
\hline$\left[\mathrm{M}_{3}+\mathrm{Na}\right]^{+}$ & $1458.6472 \mathrm{~m} / \mathrm{z}$ \\
\hline$\left[\mathrm{M}_{4}+\mathrm{Na}\right]^{+}$ & $1921.8525 \mathrm{~m} / \mathrm{z}$ \\
\hline
\end{tabular}

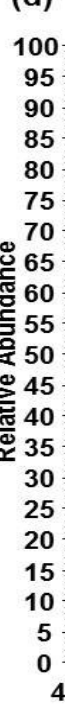

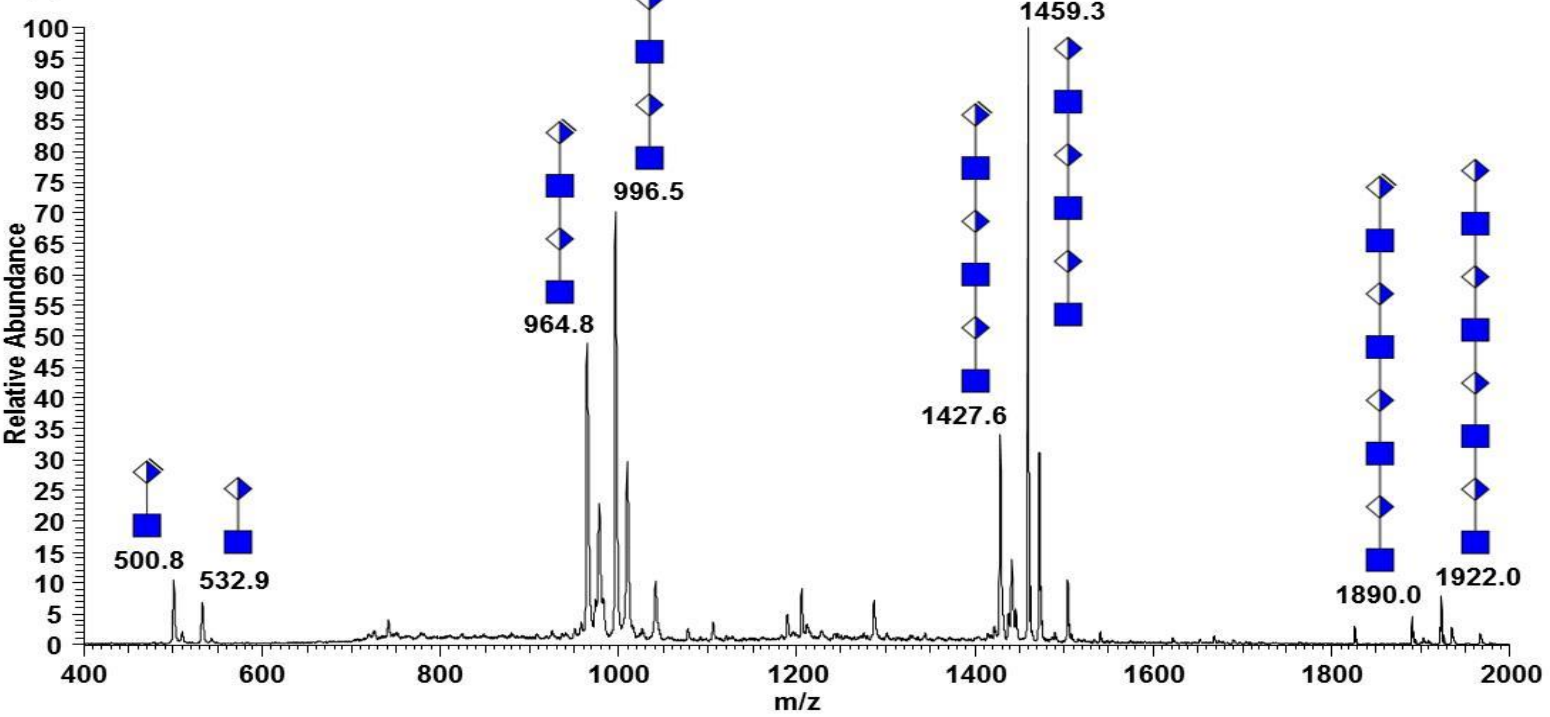

Fig. 4. ESI-MS spectra of permethylated hyaluronic acid (HA). The structure of the oligosaccharide hyaluronic acid (a) and the list of mass $(\mathrm{m} / \mathrm{z})$ corresponding to number of repeat unit (b). Mass spectra of permethylated HA from the standard (c) and F3 of Liparis tesellatus eggs (d). 
(a)

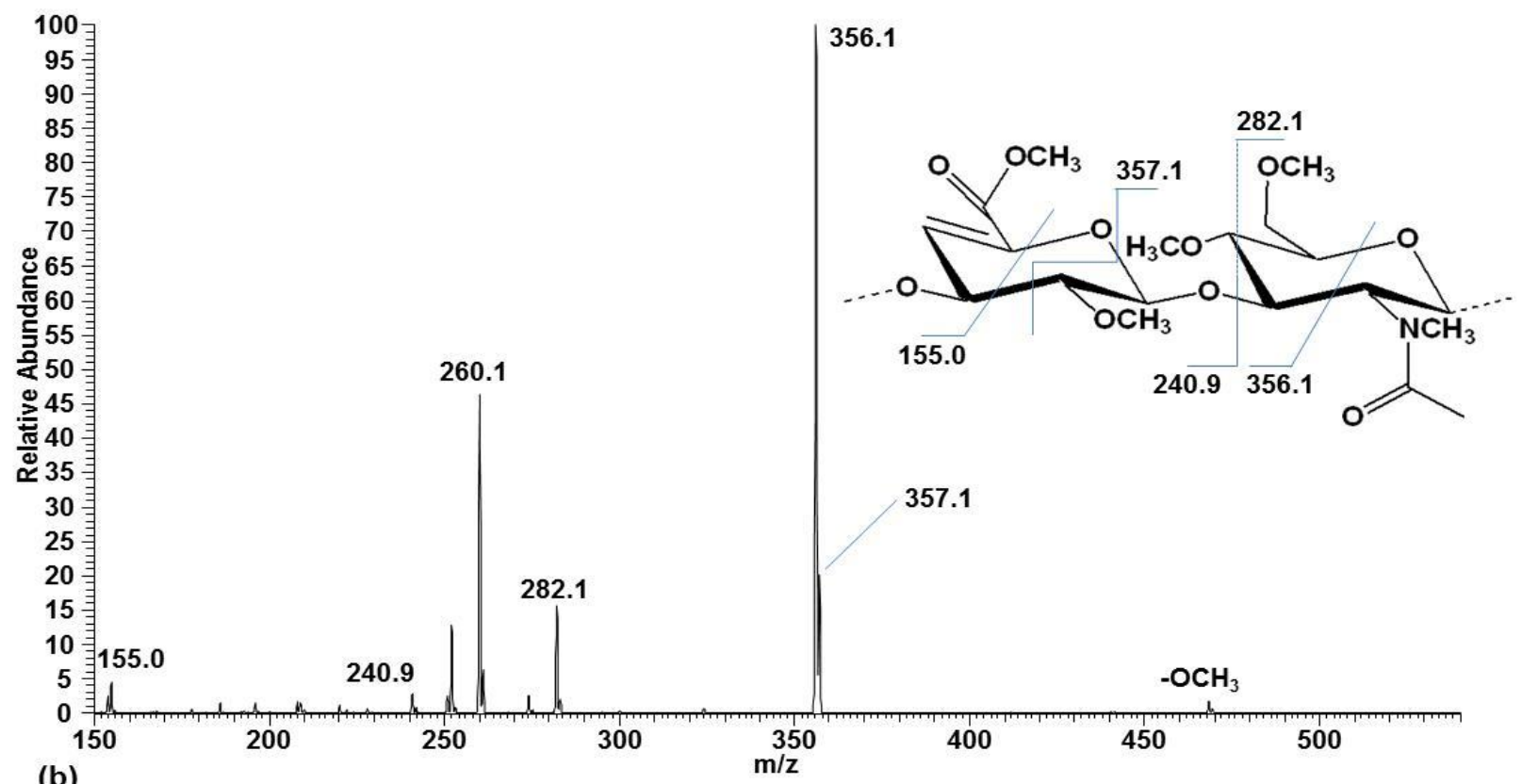

(b)

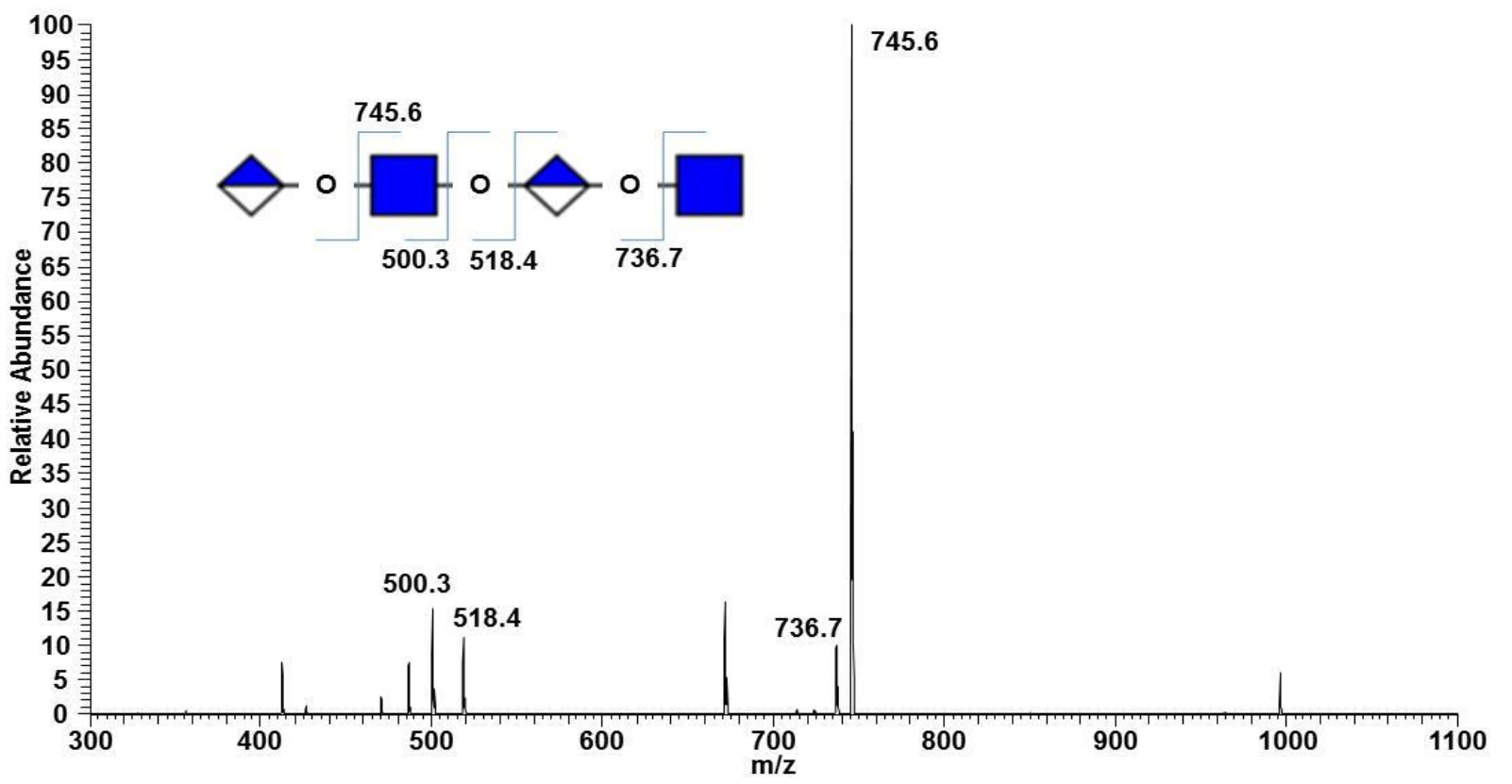

Fig. 5. MS/MS spectra of permethylated hyaluronic acids.MS/MS spectra at $\mathrm{m} / \mathrm{z} 500.8$ (a) and at $\mathrm{m} / \mathrm{z} 996.5$ (b). 
Table 1. Constituents present in the fractions F1, F2, and F3, obtained by purification of polysaccharides isolated from $L$. tesellatus eggs using a DEAE-sepharose fast flow column chromatography.

\begin{tabular}{ccccc}
\hline Fraction & Total sugar $(\%)$ & $\begin{array}{c}\text { Sulfated glycans } \\
(\%)\end{array}$ & $\begin{array}{c}\text { Uronic acids } \\
(\%)\end{array}$ & $\begin{array}{c}\text { Acetylhexosamines } \\
\text { and hexosamines } \\
(\%)\end{array}$ \\
\hline F1 & $88.5 \pm 0.3^{\mathrm{b}}$ & $26.8 \pm 0.5^{\mathrm{c}}$ & $34.6 \pm 0.1^{\mathrm{a}}$ & $23.4 \pm 1.2^{\mathrm{c}}$ \\
F2 & $81.3 \pm 2.6^{\mathrm{a}}$ & $22.9 \pm 0.1^{\mathrm{b}}$ & $35.5 \pm 2.6^{\mathrm{a}}$ & $19.0 \pm 0.1^{\mathrm{b}}$ \\
F3 & $78.4 \pm 0.8^{\mathrm{a}}$ & $20.2 \pm 0.1^{\mathrm{a}}$ & $45.5 \pm 0.8^{\mathrm{b}}$ & $7.5 \pm 0.1^{\mathrm{a}}$
\end{tabular}

Values are means \pm standard deviation of six replicates. Means in one column that do not share a letter are significantly different $(\mathrm{p}<0.05)$. 